\title{
Den farlige tausheten
}

«Hvor farlig er det å være uenig?» spurte Per Helge Måseide, redaktør av Oslo legeforenings tidsskrift Journalen, i siste utgave (1). Han etterlyste en oppmuntring til åpen meningsutveksling fra bl.a. sykehusene, Legeforeningen, universitetene og departementet og var urolig fordi leger i så liten grad bidro til den offentlige debatten. Samme bekymring ga Tidsskriftets debattredaktør Anne Kveim Lie uttrykk for i en lederartikkel tidligere i år (2): «Hvorfor unnlater leger å engasjere seg i reformer som kan ha dyptvirkende konsekvenser for deres egen praksis? Det er neppe fordi vi leger mener at våre synspunkter ikke er viktige i disse sakene. Likevel deltar vi altså i forbausende liten grad.»

Tidsskriftet har alltid vært åpent for debatt, og fra januar 2010 løftet vi meningsutvekslingene frem ved å samle ledere og debattinnlegg foran i bladet. Vi gjorde det for å understreke hvor viktig tydelige meninger, kritikk og diskusjon er for utviklingen av medisinen, helsetjenestene og god legevirksomhet. Redaksjonen mottar mange kommentarer og debattinnlegg hver eneste uke, likevel sitter vi igjen med en følelse av at noe vesentlig mangler. Gjennom samtaler med kolleger, særlig i sykehusene, får vi et klart inntrykk av frustrasjon over og bekymring for hvordan faget og tjenestene ledes og utvikler seg. Men når vi ber noen skrive om dette, er det sjelden svaret er ja. Olaf Aasland \& Reidun Førde viste i en artikkel i 2008 at sykehuslegene $\mathrm{i} ø$ kende grad syntes det var vanskelig å si fra om faglig utilfredsstillende forhold og mente dette var en trussel mot pasientsikkerheten (3). Lite tyder på at situasjonen har bedret seg, det er snarere tvert imot.

Hvordan skal vi få helsepersonell, pasienter og pårørende i tale? Deres rapportering og varsling - fra sengekanten - om hva som fungerer og hva som ikke fungerer i dagens helsevesen, er helt avgjørende for å kunne korrigere feil, drive utviklingen i riktig retning og bevare det solidarisk baserte helsevesenet vi har i Norge. Ett tiltak som Tidsskriftet har jobbet med en tid, er å utnytte ny teknologi og nye kommunikasjonsformer enda bedre for å legge til rette for fri meningsutveksling og gode samtaler om fag og helsetjeneste. Det er bakgrunnen for at vi nå har etablert en egen blogg (4) som lanseres samtidig med denne utgaven.

Hva er en blogg? Ordet er en sammentrekning av ordene web og logg, altså en slags nettdagbok. Det er ikke noen helt klar grense mellom blogger og andre nettsteder der innlegg publiseres fortløpende og kronologisk. Men bloggen har likevel noen særlige kjennetegn, f.eks. at artiklene har et kommentarfelt der leserne har anledning til å skrive egne innlegg. Det finnes mange millioner blogger - ingen har oversikt over hvor mange. Innholdet varierer tilsvarende: fra det skravlete og private til det alvorlige og unike. Mange av verdens mest besøkte blogger blir publisert av «vanlige» redaksjoner i kjente mediebedrifter. Den velrenommerte avisen The New York Times publiserer nå 50 ulike blogger (5).

Et blogginnlegg skal ideelt sett invitere til en dialog mer enn presentere en fiks ferdig argumentasjon. I en samtale er det lov å komme med utspill og tanker som ikke er helt ferdigtenkt. Det er det også rom for på bloggen. Noen ganger er det kanskje nettopp utspillene og kommentarene samlet som skaper den fulle meningen? Språkbruken kan også være mer uformell enn i en tradisjonell tidsskriftartikkel.

Det vil ikke være fritt frem for alle slags ytringer på Tidsskriftets blogg. Vi ønsker en tone preget av respekt og saklighet og har utarbeidet egne retningslinjer for innlegg. Alle kommentarer blir lest og moderert av redaksjonen før publisering, og vi forbeholder oss retten til å la være å publisere kommentarer og til å sette strek i debatter. Innlegg og kommentarer som strider mot norsk lov eller alminnelig folkeskikk vil ikke bli publisert. Det samme gjelder bilder eller lenker som viser til nettsteder med ulovlig eller upassende innhold. Ved deling av kasuistikker gjelder samme regler for anonymisering og samtykke som for øvrige artikler i Tidsskriftet (6).

Vi vil ikke tillate ryktespredning om enkeltpersoner, men det er tillatt på en saklig måte å diskutere offentlige personer i kraft av deres verv. Innlegg som inneholder reklame for produkter eller kommersielle bedrifter, vil ikke bli publisert. Og du kan ikke uten videre kreve kommentarer fjernet $i$ ettertid. Alle temaer som er relevante for leger og medisinen er interessante. I første omgang har vi faste bloggere, mens kommentarfeltet er åpent for alle. Vil du sende inn et blogginnlegg til vurdering, er du velkommen til det (4). Det er ikke ønskelig med innlegg som er publisert tidligere. Du oppfordres til å skrive under fullt navn, slik de aller fleste andre forfattere i Tidsskriftet gjør. Men vi vil også vurdere å akseptere at kommentarer publiseres anonymt hvis dette er den eneste måten argumenter og faktaopplysninger kan komme frem på.

Hvor farlig er det å være uenig? Å tale makta midt imot er ikke uten risiko for enkeltpersoner i et lite land som Norge. Det er sjelden varslere eller folk med meninger som avviker fra de etablerte sannheter kommer særlig godt ut av det personlig og karrieremessig. Men spørsmålet kan også stilles motsatt: Hvor farlig er ikke (tilsynelatende) total enighet? Ordtaket «Tale er sølv, men taushet er gull» kan visstnok spores tilbake til de gamle egyptere. Men taushet er ikke gull når den dekker over forhold det bør snakkes høyt om eller den hindrer alternative oppfatninger i å komme frem. Vår blogg er opprettet for å forenkle meningsutvekslingen og samtalen om disse forholdene. Gå inn på http://blogg.tidsskriftet.no og gi oss innspill!

\section{Charlotte Haug}

redaktør

\section{Stine Bjerkestrand}

utviklingsredaktør

\section{Litteratur}

1. Måseide PH. Hvor farlig er det å være uenig? Journalen 2010; 3: 3 .

2. Lie AK. La oss diskutere. Tidsskr Nor Legeforen 2010; 130: 471.

. Aasland OG, Førde R. Legers faglige ytringsfrihet. Tidsskr Nor Legeforen 2008 128: $1838-40$

4. Tidsskriftets blogg. http://blogg.tidsskriftet.no (26.8.2010).

5. The New York Times. www.nytimes.com/interactive/blogs/ directory.html?scp=1-spot\&sq=blogs\&st=cse (15.8.2010).

6. Tidsskriftets forfatterveiledning. Anonymisering og informert samtykke. www.tidsskriftet.no/?nota_id=965 (15.8.2010). 